\section{Nauplius}

The Journal of The

Brazilian Crustacean Society

e-ISSN 2358-2936

www.scielo.br/nau www.crustacea.org.br
This article is part of the tribute offered

by the Brazilian Crustacean Society

in memoriam of Michael Türkay for his

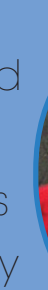

\title{
Catalogue and illustrated key of Achelous De Haan, 1833 and Portunus Weber, 1795 (Brachyura: Portunidae: Portuninae) species occurring in Brazilian waters
}

\author{
Iana Barbosa Rodrigues ${ }^{1}$, Irene Azevedo Cardoso ${ }^{1}$ \\ and Cristiana Silveira Serejo ${ }^{1}$
${ }^{1}$ Museu Nacional/UFRJ, Quinta da Boa Vista s/n. 20940-040 Rio de Janeiro, Rio de Janeiro, Brazil. \\ ZOOBANK http://zoobank.org/urn:lsid:zoobank.org:pub:BF502AD5-6E85-4381- \\ A7D8-BEB974713587
}

\begin{abstract}
The subfamily Portuninae includes about 130 species organized in 11 genera. The genera Portunus (Weber, 1795) and Achelous (De Haan, 1833) include about 80 species altogether. In Brazilian waters there are five known species of Achelous and four of Portunus. In the present contribution, a catalogue and illustrated key are provided for all Brazilian Achelous and Portunus species known to date.
\end{abstract}

KEY WORDS

Brazil, morphology, Portunoidea, taxonomy, Western Atlantic.

CORRESPONDING AUTHOR Irene Azevedo Cardoso irenecardoso@mn.ufrj.br

SUBMITTED 1 July 2016 ACCEPTED 17 November 2017 PUBLISHED 6 April 2017

Guest Editor

Célio Magalhães

DOI 10.1590/2358-2936e2017005

\section{INTRODUCTION}

The subfamily Portuninae Rafinesque, 1815 includes about 130 species organized in 11 genera. The genera Portunus (Weber, 1795) and Achelous (De Haan, 1833) include about 80 species altogether (Mantelatto et. al., 2007). Mantelatto et al. (2009) in a molecular analysis demonstrated that Portunus is a polyphyletic genus, and comprises a clade including two groups of species from different genera. One of these groups includes all American 
Portunus species except Portunus sayi (Gibbes, 1850) and Cronius tumidulus (Stimpson, 1871), and to name this monophyletic group (ten species) they elevated the subgenus Achelous to generic level, with Achelous spinimanus (Latreille, 1819) as the type species. Herein we follow these changes in classification. In Brazilian waters, there are five known species of Achelous: Achelous gibbesii (Stimpson, 1859), Achelous ordwayi Stimpson, 1860; Achelous rufiremus (Holthuis, 1959); Achelous spinicarpus Stimpson, 1871 and A. spinimanus; and four species of Portunus: Portunus anceps (Saussure, 1858); Portunus floridanus Rathbun, 1930; P. sayi and Portunus ventralis (A. Milne-Edwards, 1879) (Melo, 1996; Mantelatto et al., 2007; Coelho et al., 2008).

A catalogue with taxonomic data, e.g., diagnosis, distribution, habitat and type locality of these species is presented herein. An illustrated key to all Brazilian Achelous and Portunus species is also provided. The Portunus and Achelous species found in Brazilian waters all have a geographic distribution restricted to the Central and Western Atlantic, occurring on different types of substrates, such as hard and soft bottoms, mud, gravel, broken shells, at depths from shallow waters up to $640 \mathrm{~m}$ (Williams, 1984; Melo, 1996).

\section{Material and Methods}

The material examined herein belongs to the collections of Crustacea from Museu Nacional, Universidade Federal do Rio de Janeiro (MNRJ) and from the Departamento de Oceanografia, Universidade
Federal de Pernambuco (DOUFPE). The following measuremens were taken: carapace width (cw) and carapace length $(\mathrm{cl})$. Measurements are always presented in millimeters. Data on $P$. floridanus and $P$. sayi were taken from the literature (Rathbun, 1930; Williams, 1984). The nomenclature of the anterior part of the carapace used was: $\mathrm{mt}$ (median teeth), sm (submedian teeth), lt (lateral frontal teeth) (Figs. 1A, B); to the teeth at lateral part of carapace the term anterolateral teeth was used.

\section{Systematics}

\section{Family Portunidae Rafinesque, 1815}

Subfamily Portuninae Rafinesque, 1815

Genus Achelous De Haan, 1833

Achelous gibbesii (Stimpson, 1859)

(Fig. 2A)

Material examined. Brazil, Maranhão, Tutóia, 1 female (cw 36; cl 22), DOUFPE 7120.

Diagnosis. Carapace approximately twice as wide as long, not protuberant, with small spherical granules, pubescent, and with naked, transverse ridges, two of which arise from posterior anterolateral tooth and arch toward gastric region. Frontal region with eight teeth; median teeth and submedian teeth more advanced than lateral frontal teeth 1 and 2, these two pairs subequal

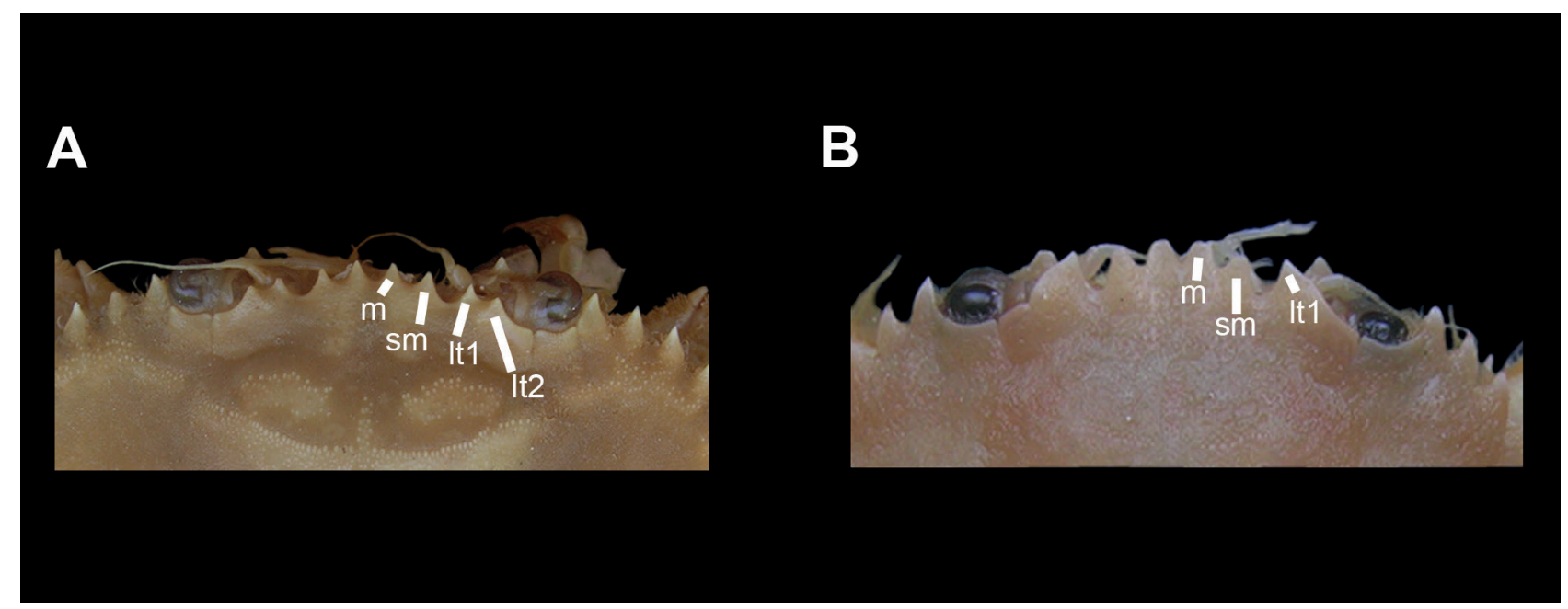

Figure 1. Nomenclature of frontal teeth used in Achelous and Portunus. A, Specimen with 8 frontal teeth; B, specimen with 6 frontal teeth (m, median teeth; sm, submedian teeth; lt, lateral frontal teeth). 
in size. Posterior anterolateral tooth, slender, sharp, curved slightly forward and about as long as space occupied by three preceding teeth. Chelipeds long, slender (especially in males); merus with four to seven spines in front and one spine behind at distal end, carpus with large internal and smaller external spine. Merus of swimming leg with row of spinules on posterodistal edge (modified from Williams, 1984).

Measurements. Carapace: male, cl 37, cw 76; ovigerous female, cl 35, cw 66 (Williams, 1984). Male, cl 29, cw 56.4, width between anterior bases of lateral spines 46.4 (Rathbun, 1930).

Color. Brownish red, transverse ridges on carapace, spines and margins of chelipeds carmine red; front side of legs brilliantly iridescent by lantern light, iridescence evident to some extent in preserved specimens (Williams, 1984).

Geographic distribution. Western Atlantic: USA (Massachusetts to Florida), Gulf of Mexico (USA, Florida to Mexico, Cancun), Venezuela, Guyana and Brazil (Maranhão) (Coelho and Ramos-Porto, 1992; Almeida \& Coelho, 2008); Caraguatatuba, SP (GBIF, 2016).

Type localities. St. Augustine and the Keys, Florida (USA).

Habitat. From surface to $90 \mathrm{~m}$. On mud, sand and broken shells bottom. Usually in deeper parts of bays and estuaries (Melo, 1996).

\section{Achelous ordwayi Stimpson, 1860}

(Fig. 2B)

Material examined. REVIZEE PESCA: \#A1, $19^{\circ} 43^{\prime} 55^{\prime \prime S} 38^{\circ} 21^{\prime} 54^{\prime \prime} \mathrm{W}, 72 \mathrm{~m}, 1$ male (cw 3.5 ; cl 2.5) and 1 female (cw 3.4; cl 2.4), MNRJ 17068; REVIZEE BENTHOS: \#5, 20 m, 1 male (cw 3.6; cl 2.5), MNRJ 16244.

Diagnosis. Carapace approximately 1.5 times wider than long, uneven, elevations granulate and depressions pubescent, with a number of conspicuous, curving transverse ridges; margin more or less fringed with silky hair, as well as the chelipeds. Frontal region with six teeth; median teeth and submedian teeth about equal in size, strong and well defined, triangular, acute, median teeth advanced beyond others; acuminate lateral frontal teeth 1. Posterior anterolateral tooth about as long as space occupied by 2 preceding teeth, tips of all acute and turned forward. Chelipeds of moderate length; merus with four to six strong spines in front, single distal spine behind; carpus ribbed, with strong internal and much smaller external spine. Merus of swimming leg without posterodistal lobe but spinulose (modified from Williams, 1984).

Measurements. Carapace: male, cl 33, cw 49; ovigerous female, cl 32, cw 50 (Williams, 1984). Female, cl 33.3, cw 47, width at anterior base of lateral spine 41.6 (Rathbun, 1930).

Color. Carapace and legs reddish brown because of fine mottling with red, yellowish brown and gray; pale orange beneath, deeper orange on chelipeds and legs; chelae deep red brown above, finger with 2 cross bands of light orange red. Blue coloration also apparent near red and dark pigments; hairs on appendages deep red (Williams, 1984).

Geographic distribution. Western Atlantic: USA (Massachusetts to Florida), Gulf of Mexico (USA, Florida to Mexico, Cancun), Antilles, Venezuela, Guyana and Brazil (Amapá to Rio Grande do Sul, and Fernando de Noronha) (Melo, 1996).

Type localities. Key Biscayne and Tortugas (Florida, USA), St. Thomas.

Habitat. From surface to $110 \mathrm{~m}$. On sand, gravel, broken shells and coral bottom (Melo, 1996).

\section{Achelous rufiremus (Holthuis, 1959)}

(Fig. 2C)

Material examined. \# 313, Brazil, Amapá, Amazonas River, $01^{\circ} 46^{\prime} \mathrm{S} 48^{\circ} 21^{\prime} \mathrm{W}$, 46-47 m, mud bottom, 1 male (cw 2.5; cl 1.6), MNRJ 301. 


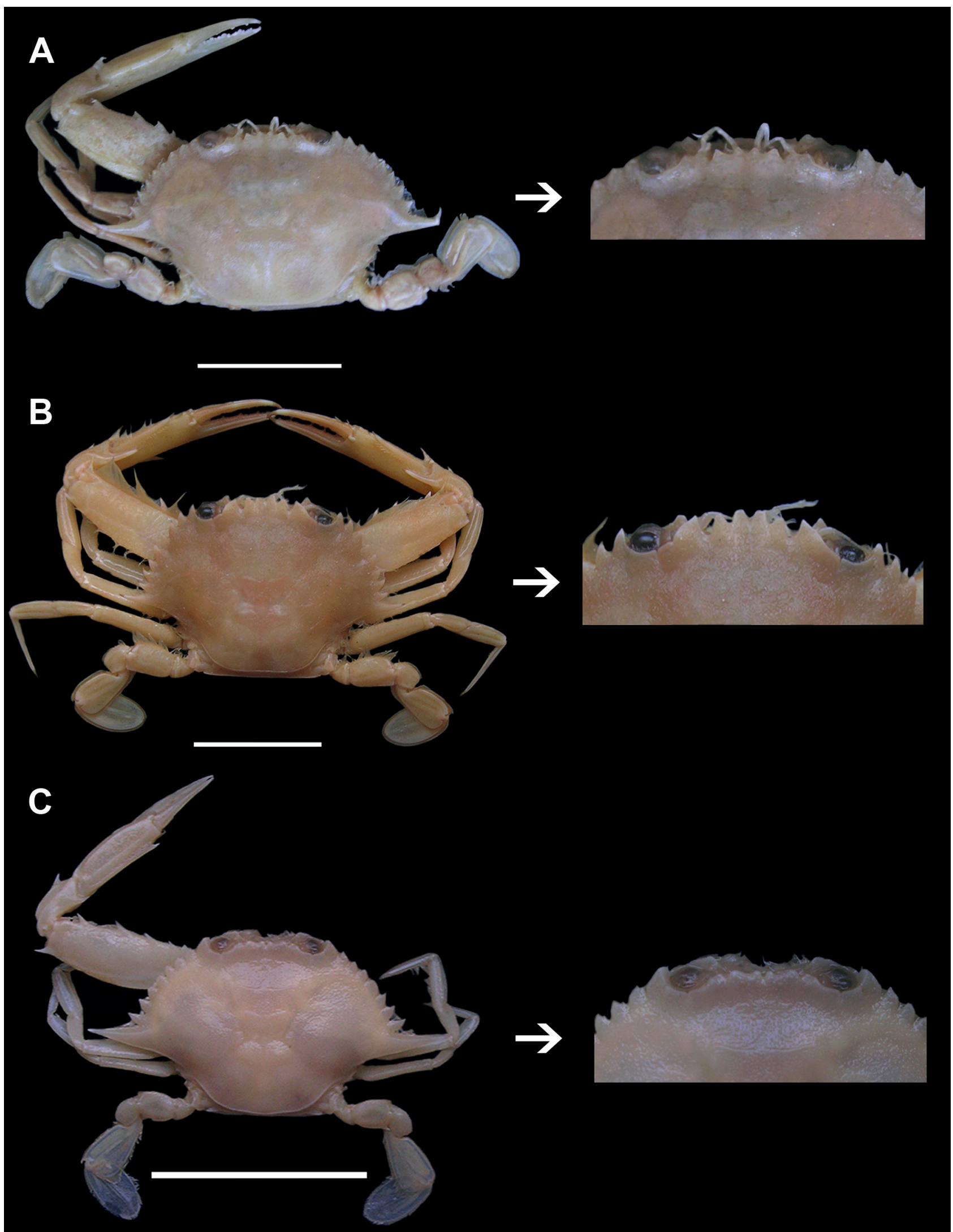

Figure 2. A, Achelous gibbesii, DOUFPE 7120; B, Achelous ordwayi, MNRJ 16244; C, Achelous rufiremus, MNRJ 301. Scale bars: $2 \mathrm{~cm}$. 
Diagnosis. Carapace densely granular and pubescent; granules rather evenly distributed, but forming two distinct transverse rows in the gastric area: one on the line between meso- and meta-gastric regions, and one somewhat more anteriorly and interrupted in the middle; naked spot near postero-lateral margin. Frontal region with six teeth; median teeth bluntly triangular or rounded and separated from one another by a U-shaped sinus; submedian teeth very broad at the base and a top bluntly rounded, separated from median teeth by a very wide sinus, and from lateral frontal teeth 1 by a much narrower sinus; median teeth and submedian teeth about equally far forwards, slightly overreaching lateral frontal teeth 1 . Posterior anterolateral tooth very strong, distinctly more than twice as long as the preceding and directed straight outwards. Chelipeds very long, pubescent and with granular carinae; merus with four to six strong spines on inner margin and one at the distal end of outer margin; upper surface bearing granules and short hairs; carpus with two strong spines on anterior margin, one in the inner and one in the outer part. Merus of swimming legs about as long as broad; posterior margin with distinct spine (modified from Holthuis, 1959).

Measurements. Only record of one male belonging to the MNRJ: cw 25, cl 16.

Color. Preserved specimens: carapace pale reddish brown. Legs still paler reddish brown above. Lower surface is yellowish white. Spines on inner margin of the merus of chelipeds are dark red, as are also the inner spine of carpus and tips of fingers. Distal joints of second to fourth pereopods are pinkish, while distal half of dactylus of the swimming legs has a dark red spot (Holthuis, 1959).

Geographic distribution. Western Atlantic: Guyana, Brazil (Amapá, Pará and Maranhão) (Melo, 1996; Viana et al., 2003).

Type locality. Between mouths of the Suriname and Marowijne Rivers, $6^{\circ} 44^{\prime} \mathrm{N} 54^{\circ} 31^{\prime} \mathrm{W}$; mud bottom; depth $42 \mathrm{~m}$.

Habitat. At depths of $20 \mathrm{~m}$ to $45 \mathrm{~m}$, on mud, shells and coral bottom (Holthuis, 1959).

\section{Achelous spinicarpus Stimpson, 1871}

(Fig. 3A)

Material examined. Brazil, Rio de Janeiro, Cabo Frio, $60 \mathrm{~m}, 6$ males (cw 4.5-5.0; cl 2.9-3.1) and 4 females (cw 3.2-3.9; cl 2.0-2.4), MNRJ 5028.

Diagnosis. Carapace about twice wider than long; sculptured, with a number of naked, rather coarsely granulate, arching, transverse ridges separated by finely granulate and pubescent surfaces. Frontal region with six to eight teeth; median teeth and submedian teeth narrow, acute, separated by broad usually U-shaped notches, median teeth considerably advanced beyond submedian teeth; lateral frontal teeth 1 and 2 with sinuate but unknotted outer margins. Posterior anterolateral tooth slender, curving, more than half of anterolateral border length and directed outwards. Chelipeds long, slender; merus with four or five stout, curved spines in front, and single, similar, distal spine behind; carpus with two spines, outer spine small and weak, inner spine long, extending along the side of hand to near base of dactyl; Merus of swimming leg irregularly spinose or denticulate in postero-distal angle (modified from Rathbun, 1930 and Williams, 1984).

Measurements. Male, cl 34, cw 64; female, cl 32, cw 58 (Williams, 1984).

Color. Carapace grayish green marbled with short, curved reddish brown line and streaks; a dark median longitudinal line over cardiac and intestinal regions; epibranchial line dark red distally. Cheliped with merus very lightly spotted; carpus with long spines uninterruptedly red proximally fading to white intervals distally and fringed with long red hairs; walking legs grayish green with pink dactyls (modified from Williams, 1984)

Geographic distribution. Western Atlantic: USA (North to South Carolina, Florida), Gulf of Mexico (USA, Florida to Mexico, Cancun), Antilles, Colombia, Venezuela, Guyana, Brazil (Amapá to Rio Grande do Sul) (Melo, 1996).

Type locality. Florida Straits, USA $\left(24^{\circ} 23^{\prime} \mathrm{N}\right.$ 8257’W) (Holthuis, 1969). 


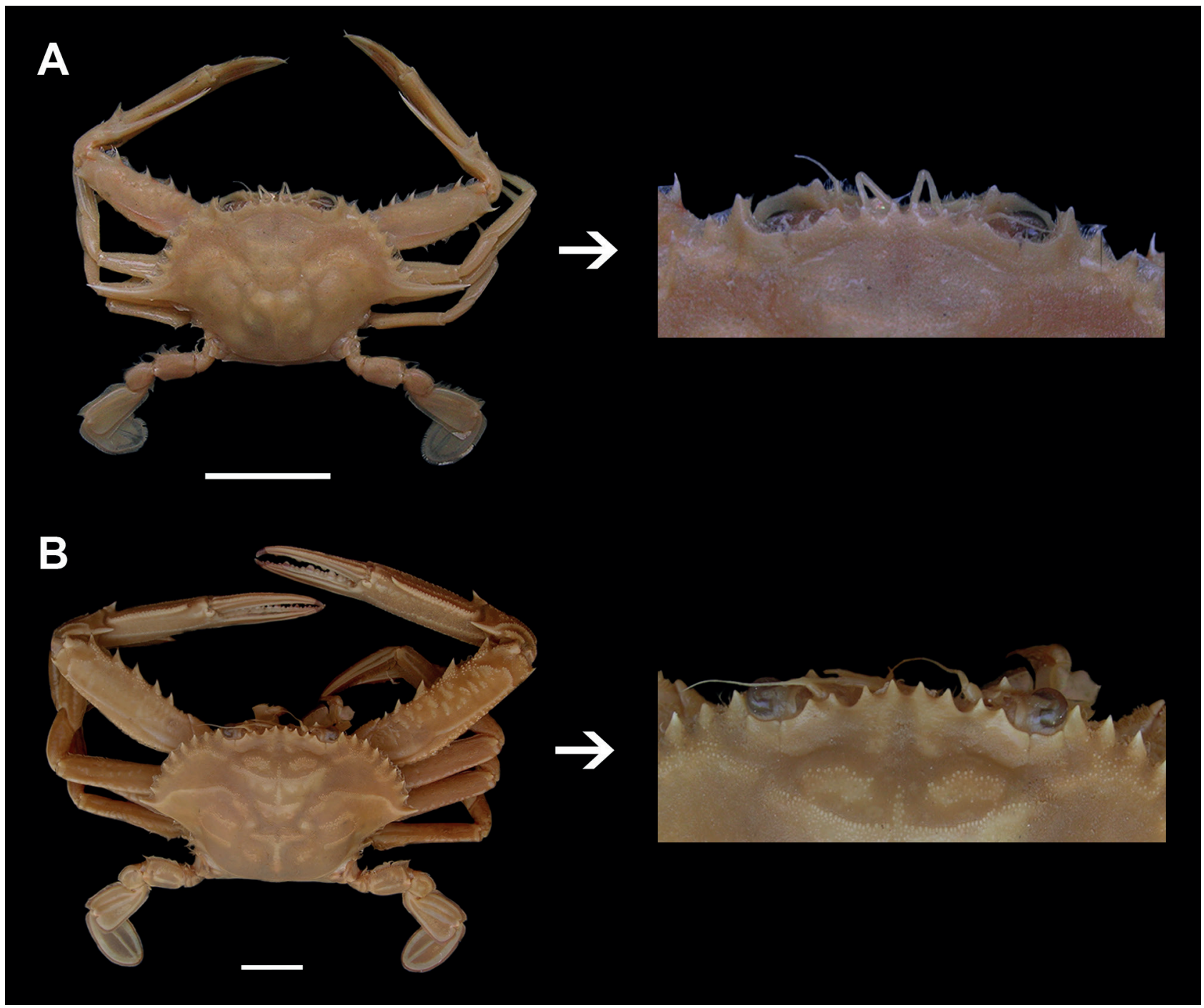

Figure 3. A, Achelous spinicarpus, MNRJ 5028; B, Achelous spinimanus, MNRJ 309. Scale bars: 2 cm.

Habitat. From shallow waters to depths of $550 \mathrm{~m}$. On sand, gravel, broken shells, corals and mud bottom (Melo, 1996).

\section{Achelous spinimanus (Latreille, 1819)} (Fig. 3B)

Material examined. Brazil, Rio de Janeiro: Ilha do Governador, Praia do Zumbi, 2 male (cw 7.6-7.8; cl 4.9) MNRJ 309; Arraial do Cabo, Prainha, 1 male (cw 8.8; $\mathrm{cl} 5.6$ ) and 1 female (cw 5.8; cl 3.9), MNRJ 857.

Diagnosis. Carapace considerably less than twice wider than long, finely granulate and pubescent, with number of prominent, curved, coarsely granulate, transverse ridges. Frontal region with eight teeth; median teeth slightly narrowed and more advanced than submedian teeth, all considerably more advanced than lateral frontal teeth 1 and 2. Posterior anterolateral tooth about twice as large as others and usually curved forward. Chelipeds long, pubescent, serratogranulate all over; merus with four, occasionally five strong, curved spines on anterior margin and one spine at distal end; carpus with two spines, inner one much stronger, and with four conspicuous ridges on upper surface and outer spine small. Merus of swimming leg with a very short blunt spine at postero distal angle, followed by a row of spinules on distal margin (modified from Rathbun, 1930 and Williams, 1984).

Measurements. male, cl65, cw 110; ovigerous female, cl 57, cw 94 (Williams, 1984). Male, cl 61.7, cw 85.6, width at anterior base of lateral spine 77.7. Male (S.U.I.) from Bahama Banks, cl 58, cw $9.5 \mathrm{~cm}$ (Rathbun, 1930). 
Color. Pubescence yellowish or reddish brown, ridges of carapace, spines and chelipeds, finger and tips of legs reddish brown; anterolateral teeth reddish at base, white at tips; merus, carpus and hand of chelipeds with white blotches (Williams, 1984).

Geographic distribution. Western Atlantic: USA (New Jersey to southern Florida), Bermuda, Gulf of Mexico (USA, Florida to Mexico, Cancun), Antilles, Venezuela, Guyana, Brazil (Amapá to Rio Grande do Sul) (Mesquita, 1972; Barreto et al., 1993; Coelho and Ramos-Porto, 1992; Melo, 1996; Coelho Filho, 2006).

Type locality. American waters (Rathbun, 1930).

Habitat. From surface to depths of $90 \mathrm{~m}$. Brackish water of channels and bays, on sand, gravel, broken shells and mud bottom (Melo, 1996).

\section{Genus Portunus Weber, 1795}

\section{Portunus anceps (Saussure, 1858)}

(Fig. 4A)

Material examined. REVIZEE Benthos: \#49, 20³1'18”S 29²1'03”W, 50-65 m, 1 male (cw, 2.6 cm; cl $1.6 \mathrm{~cm})$, MNRJ 16515.

Diagnosis. Carapace twice wider than long, pubescent, with several indistinct, arching, granulate, transverse ridges. Frontal region with six teeth, median teeth shortest one, submedian teeth largest one, and lateral frontal teeth 1 blunt. Posterior anterolateral tooth sharp, slender, and about as long as space occupied by four preceding teeth, tip trending forward. Chelipeds long; merus with four spines in front, a distal spine behind; carpus ridged, with strong inner and a smaller outer spine. Merus of swimming leg with postero-distal margin oblique, unarmed (modified from Rathbun, 1930 and Williams, 1984).

Measurements. male, cl 13, cw 26; female, cl 15, cw 29 (Williams, 1984).

Color. Background color off-white, carapace with some brown mottling; Posterior anterolateral tooth of carapace with brown spot at mid length; chelipeds with brown spot dorsally at distal two-thirds, smaller spot distally; carpus, propodus, and basal third of dactylus of cheliped each with brown spot; merus, carpus, and propodus of walking legs with brown spot near midlength; distal segment of fifth leg white (Manning and Chace, 1990).

Geographic distribution. Western Atlantic: USA (North Carolina, Florida), Bermuda, Gulf of Mexico (USA, Florida to Mexico, Cancun), Antilles, Brazil (Amapá to Rio de Janeiro) (Melo, 1996). Central Atlantic: Ascension Island (Manning and Chace, 1990; Melo, 1996).

\section{Type locality. Cuba.}

Habitat. From shallow waters to $20 \mathrm{~m}$. Mainly on sand bottoms, with burying habit, but also on mud, shells, hard substrate, and sea-grass beds (Manning and Chace, 1990; Melo, 1996).

\section{Portunus floridanus Rathbun, 1930}

(Fig. 4B)

Diagnosis. Carapace narrow, with many short setae, inconspicuous, without strong ridges but with extensive pattern formed by tracts of fine granules. Frontal region with six teeth; median teeth shortest one, submedian teeth blunt and largest than others, and lateral frontal teeth 1 triangular, similar in shape to submedian teeth, and with a single conspicuous central fissure on upper orbital margin. Posterior anterolateral tooth short, strong, larger than adjacent teeth, tips trending forward. Chelipeds long, granulate, with ridges; merus with three to five spines on anterior border and small curved spine at distal end of posterior border; carpus ridged and finely granulate, small outer spine and broad inner spine larger than propodal spine at articulation. Merus of swimming leg longer than wide, armed distally along posterior margin with row of spinules (modified from Williams, 1984).

Measurements. Male, cl 23, cw 47; female, cl 19.5, cw 25 (occasionally 30) (Williams, 1984). Male holotype, cl 13, cw 20.6, width at anterior base of lateral spine 17.6, fronto-orbital width 11.8 ; female paratype, $\mathrm{cl}$ 15.2, cw 23.2 (Rathbun, 1930). 


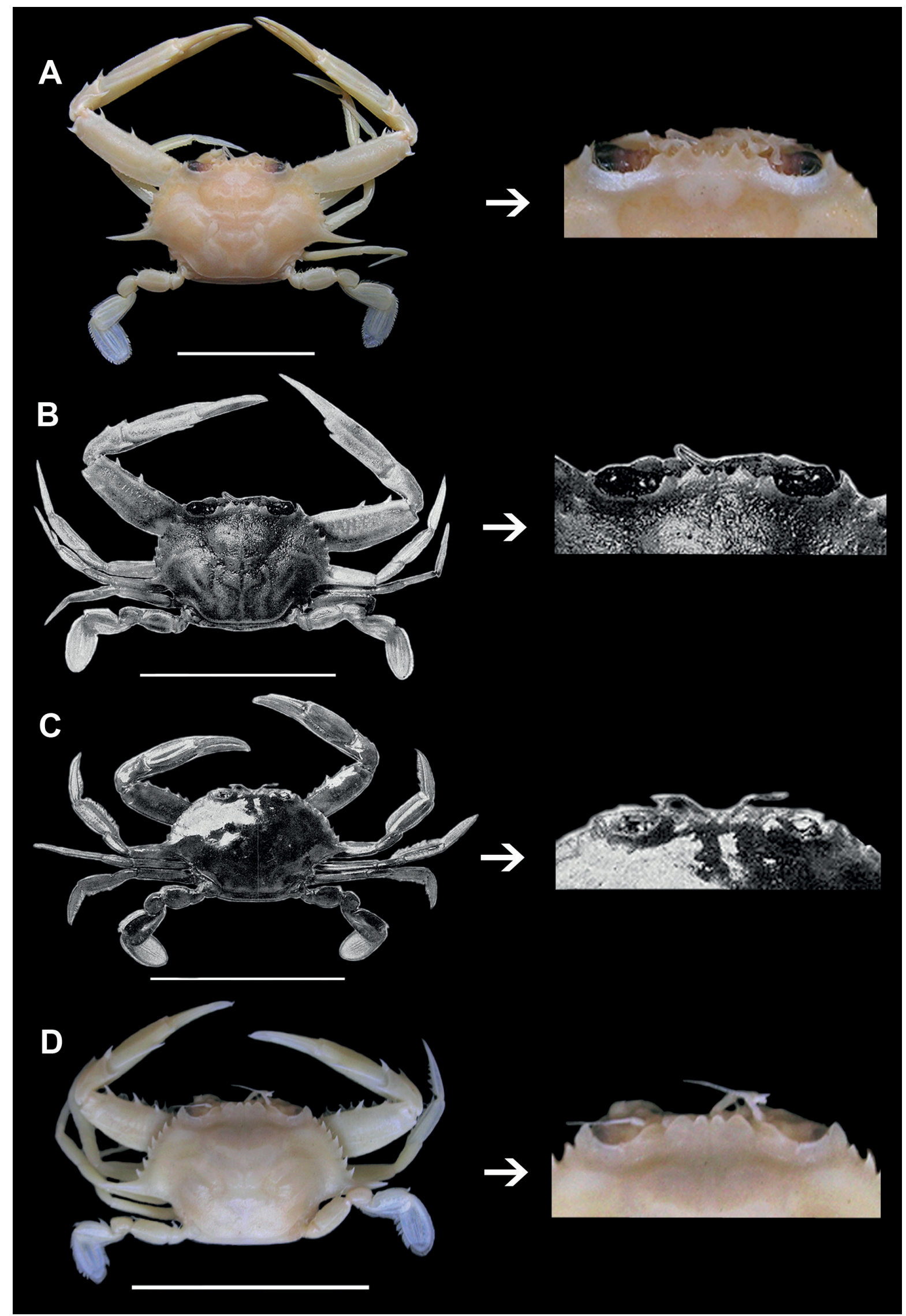

Figure 4. A, Portunus anceps, MNRJ 16515; B, Portunus floridanus (from Rathbun, 1930); C, Portunus sayi (from Rathbun, 1930); D, Portunus ventralis, DOUFPE 7215. Scale bars: A, B, D, $2 \mathrm{~cm}$; C, $3.7 \mathrm{~cm}$. 
Geographic distribution. Western Atlantic: USA (North Carolina) to Honduras and Nicaragua, Antilles, Surinam, Brazil (Paraíba) (Williams, 1984; RamosPorto et al., 2000).

Type locality. Off Key West, Florida (USA), from coral bottom, $82 \mathrm{~m}$.

Habitat. Hard bottom, muddy sand or mud in some localities; at depths of 9 to $640 \mathrm{~m}$, but most common from 60 to $80 \mathrm{~m}$ (Williams, 1984)

\section{Portunus sayi (Gibbes, 1850)}

(Fig. 4C)

Diagnosis. Carapace nearly twice wider than long, somewhat tumid, smooth and polished to naked eye, finely granulate under magnification. Frontal region with six teeth; median teeth small but about equally advanced with submedian teeth, lateral frontal teeth 1 rounded and larger than median teeth and submedian teeth. Posterior anterolateral tooth acute, strong, about as long as space occupied by 2 preceding teeth and directed outwards. Chelipeds of moderate length, somewhat larger in males than in females; merus with three to four stout, curved spines in front, none spine behind; carpus with two spines, a strong one at inner angle of carpus and a smaller spine near distal end of outer margin; a noticeable ridge above lateral margin. Swimming legs unarmed (modified from Rathbun, 1930 and Williams, 1984).

Measurements. Male, cl 31, cw 61; ovigerous female, cl 31, cw 64 (Williams, 1984). Male, cl 29, cw 55.6, width at anterior base of lateral spine 47.7; female, $\mathrm{cl}$ $37.1, \mathrm{cw} 76.1$, width at anterior base of lateral spine 62.7 (Rathbun, 1930).

Color. Chocolate brown or purplish with cloudings of olive green or light brown and irregular white or flesh-colored spots; orange margins on spines of chelipeds (Williams, 1984).

Geographic distribution. Western Atlantic: Canada (Nova Scotia, $43^{\circ} \mathrm{N}$ ) to USA (North Carolina, South Carolina), Gulf of Mexico (USA, Florida to Mexico, Cancun), Guyana, Bermuda, Brazil (Paraíba) (Melo and Veloso, 2005).
Habitat. Normally this is a pelagic form living among floating Sargassum, but it is occasionally carried into coastal areas by currents (Williams, 1984).

Type locality. South Carolina, USA.

\section{Portunus ventralis (A. Milne-Edwards, 1879) (Fig. 4D)}

Material examined. Sald \#1655, 1 male (cw 1.7; cl 1.1), DOUFPE 7215.

Diagnosis. Carapace short pubescent and with coarse granulation. Frontal region with six teeth; median teeth smaller than submedian teeth; median teeth almost semicircular or with arcuate edge; lateral frontal teeth 1 blunt and considerably shorter than submedian teeth. Posterior anterolateral tooth broad at base, as long as the space occupied by the three adjacent teeth, and curved a little forward. Chelipeds of moderate length; merus with four spines, two on distal half of the inner margin and much longer and stronger than the pair of spines on the proximal half; at the distal end of the outer margin there is no spine; carpus with two spines, one at the inner angle and one on the outer side, the first longer and stronger then the last one. Merus of swimming leg unarmed (modified from Rathbun, 1930).

Measurements. Female, cl 14.2, cw 27.4, width at base of lateral spine 22.2 (Rathbun, 1930).

Color. On the carapace a large postero-lateral area and a postorbital triangle are slate-color, as are also the greater part of the upper surface of the merus of the cheliped, the infero-proximal two-thirds of outer face of manus and the basal half of fingers; rest of surface a sort of ecru drab and buff pink; fingers distally almost salmon buff with extreme tips nearly white. The ambulatory legs have areas of gray on the middle portion of merus, carpus and propodus, these patches being much less extensive on the third ambulatory, where there is also a small patch of maroon on the same three articles; a maroon spot on merus and propodus of swimming leg; remainder of this propodus as well as the whole of the dactylus transparent (modified from Rathbun, 1930). 
Geographic distribution. Western Atlantic: USA (Georgia, Florida), Gulf of Mexico (USA, Florida to Mexico, Cancun), Antilles, Venezuela, Brazil (Rocas Atoll, Rio Grande do Norte to Rio de Janeiro) (Melo, 1996; Coelho-Filho, 2006).
Habitat. From intertidal zone to depths of $25 \mathrm{~m}$. On sand bottom on sandy beaches. Also in tide pools (Melo, 1996).

Type locality. Guadeloupe, Caribbean Sea.

\section{Key to species of Achelous and Portunus occurring in Brazilian waters}

1 Dactyli of pereiopods 2-4 relatively broad, lanceolate, leaf-like or cultriform, indistinctly costate ................ 2

1 ' Dactyli of pereiopods 2-4 ensiform or cultriform, markedly costate

2 Lateral frontal teeth 1 rounded and longer than median teeth and submedian teeth P. sayi (Fig. 4C)

2' Lateral frontal teeth 1 blunt and considerably shorter than median teeth and submedian teeth P. ventralis (Fig. 4D)

3 Carpus of chelipeds with inner spine long, extending along the side of hand to near base of dactyl A. spinicarpus (Fig. 3A)

3' Carpus of chelipeds with inner spine short not extending along the side of hand 4 4 Frontal region with eight teeth 5 (Fig. 1A) 4' Frontal region with six teeth 6 (Fig. 1B)

5 Posterior margin of merus of swimming leg without a blunt spine A. gibbesii (Fig. 2A)

5 ' Posterior margin of merus of swimming leg with a short blunt spine A. spinimanus (Fig. 3B)

6 Posterior margin of merus of swimming leg with a spine A.rufiremus (Fig. 2C)

6' Posterior margin of merus of swimming leg unarmed or with a row of spinules 7

7 Posterior margin of merus of swimming leg unarmed

7 ' Posterior margin of merus of swimming leg with row of spinules P. floridanus (Fig. 4B)

8 Posterior anterolateral tooth two times longer than the remaining anterolateral teeth .. A. ordwayi (Fig. 2B) 8 ' Posterior anterolateral tooth more than five times longer than the remaining anterolateral teeth

P. anceps (Fig. 4A)

\section{General Remarks}

A morphological feature which distinguishes Achelous from Portunus following the species composition proposed in Mantelatto et al. (2007) has not been discovered yet. Verril (1908) mentioned the shape and ornamentation of the dactyli from pereopods two to four and Rathbun (1930) considered carapace width, being narrow in Achelous versus relatively wide in Portunus. These characters however separate the nine Brazilian species in two groups with a species composition distinct from that proposed at Mantelatto et al. (2007). The character proposed by Rathbun (1930) appears somewhat ambiguous. According to our observations on the Brazilian species, only A. ordwayi and $A$. rufiremus have a narrow carapace, while Melo (1996) suggested that only A. ordwayi and A. spinicarpus (treated as Portunus) have a narrow carapace. Thus we use the shape of the dactyl as the first couplet of the above key, however it does not define Achelous and Portunus as outlined by Mantelatto et al. (2007). The brachyuran classification from $\mathrm{Ng}$ et al. (2008) considered Achelous as a subgenus of Portunus including 22 species. Achelous rufiremus in this classification is considered as Portunus (Portunus) and P.floridanus is classified under Portunus (Achelous). There thus does not seem to be universal agreement about the classification of Portunus and Achelous. Much more studies have to be done to elucidate the species composition, taxonomic level and morphological diagnosis of all groups included within Portunus sensu lato (Ng et al., 2008).

\section{ACKNOWLEDgementS}

The authors are grateful to Professor Petrônio A. Coelho (in memoriam), former curator of the Collection of Crustacea from the Universidade Federal 
de Pernambuco, and to Catarina de Lourdes Araújo Silva for sending the material. We are also grateful to Dr. Sammy De Grave (Oxford University Museum of Natural History) for English language review.

\section{References}

Almeida, A.O. and Coelho, P.A. 2008. Estuarine and marine brachyuran crabs (Crustacea: Decapoda) from Bahia, Brazil: checklist and zoogeographical considerations. Latin American Journal of Aquatic Research, 36: 1-41.

Barreto, A.V.; Coelho, P.A. and Ramos-Porto, M. 1993. Distribuição geográfica dos Brachyura (Crustacea, Decapoda) coletados na plataforma continental do norte e nordeste do Brasil. Revista brasileira de Zoologia, 10: 641-656.

Coelho, P.A.; Almeida, A.O. and Bezerra, L.E.A. 2008. Checklist of the marine and estuarine Brachyura (Crustacea: Decapoda) of northern and northeastern Brazil. Zootaxa, 1956: 1-58.

Coelho, P.A. and Ramos-Porto, M. 1992. Sinopse dos crustáceos decápodos brasileiros (Portunidae). Revista brasileira de Zoologia, 9: 291-298.

Coelho Filho, P.A. 2006. Checklist of the Decapods (Crustacea) from the outer continental shelf and seamounts from Northeast of Brazil REVIZEE Program (NE III). Zootaxa, 1184: 1-27.

De Haan, W. 1833-1850. Crustacea. In: P.F. von Siebold (ed), Fauna Japonica sive Descriptio Animalium, Quae in Itinere per Japoniam, Jussu et Auspiciis Superiorum, qui Summum in India Batava Imperium Tenent, Suscepto, Annis 18231830 Collegit, Noitis, Observationibus et Adumbrationibus Illustravit. Leiden, Lugduni-Batavorum, 243p.

Gibbes, L.R. 1850. On the carcinological collections of the United States. Proceedings of the American Association for the Advancement of Science, 3: 167-201.

Holthuis, L.B. 1959. The Crustacea Decapoda of Suriname (Dutch Guiana). Zoologische Verhandelingen, 44: 1-296.

Holthuis, L.B. 1969. Portunus binoculus, n. sp., a new deep-water swimming crab from the Caribbean region (Crustacea, Decapoda, Brachyura). Bulletin of Marine Science, 19: 409-427.

Latreille, P.A. 1819. Salicoques, Carides, Latr. In: Nouveau Dictionnaire d'Histoire naturelle, appliquée aux arts, à l'Agriculture et à l'Économie rurale et domestique, à la Médecine, etc. Par une Société de Naturalistes et d'Agriculteurs. Nouvelle Édition presq'entièrement refondue et considérablement augmentée; avec des figures tirées des trois Règnes de la Nature, 30: 68-73.

Manning, R.B and Chace, F.A. 1990. Decapod and Stomatopod Crustacea from Ascension Island, South Atlantic Ocean. Smithsonian Contributions to Zoology, 503: 1-91.

Mantelatto, F.L.; Robles, R. and Felder, D.L. 2007. Molecular phylogeny of the western Atlantic species of the genus Portunus (Crustacea, Brachyura, Portunidae). Zoological Journal of the Linnean Society, 150: 211-220.
Mantelatto, F.L.; Robles, R.; Schubart, C.D. and Felder, D.L. 2009. Molecular phylogeny of the genus Cronius Stimpson, 1860, with reassignment of $C$. tumidulus and several American species of Portunus to the genus Achelous De Haan, 1833 (Brachyura: Portunidae). p. 551-565. In: J.W. Martin; K.A. Crandall and D.L. Felder (eds), Decapod Crustacean Phylogenetics. Boca Raton, London, New York: CRC Press, Taylor \& Francis Group. Crustacean Issues 18.

Melo, G.A.S. 1996. Manual de identificação dos Brachyura (caranguejos e siris) do litoral brasileiro. São Paulo, Plêiade/ FAPESP, 604 p.

Melo, G.A.S. and Veloso, V.G. 2005. The Brachyura (Crustacea: Decapoda) of the coast of the State of Paraíba, Brazil, collected by Project Algas. Revista brasileira de Zoologia, 22: 796-805.

Mesquita, A.L.L. 1972. Dados biométricos do siri canela Portunus spinimanus Latreille, 1819 (Decapoda, Brachyura, Portunidae). Arquivo de Ciências do Mar, 12: 88-90.

Milne-Edwards, A. 1879. Description de quelques Crustacés nouveaux. Bulletin de la Société philomathique de Paris, 7: 103-110.

Ng, P.K.L.; Guinot, D. \& Davie, P.J.F. 2008. Systema Brachyuororum: Part I. An annotated checklist of extant brachyuran crabs of the world. The Raffles Bulletin of Zoology, Supplement 17: 1-286.

OBIS, 2016. Ocean Biogeographic Information System: SINBIOTA - marine data (OBIS South America, BRAZIL). Accessed via http://www.gbif.org/occurrence/24676904 on 2016-06-19

Ramos-Porto, M.; Torres, M.F.A.; Viana, G.F.S.; Santos, M.C.F.; Acioli, F.D. and Cabral, E. 2000. Registers of two species of Crustacea Decapoda Brachyura in Brazilian waters. Nauplius, 8: 169-171.

Saussure, H. 1858. Memoire sur divers Crustaces nouveaux du Mexique et des Antilles. Memoires, Societe Physique et d'Histoire Naturelle de Geneve, 14: 417-496.

Rathbun, M.J. 1930. The cancroid crabs of America of the families Euryalidae, Portunidae, Atelecyclidae, Cancridae, and Xanthidae. Bulletin of the United States National Museum, 152: 1-609.

Smith, S.I. 1869. Notice of the Crustacea collected by Prof. C. F. Hartt on the coast of Brazil in 1867. Transactions of the Connecticut Academy of Arts and Sciences, 2: 1-41.

Stimpson, W. 1859. Notes on North American Crustacea, No. 1. Annals of the Lyceum of Natural History of New York, 7: 49-93, pl. I.

Stimpson, W. 1860. Notes on North American Crustacea, in the Museum of the Smithsonian Institution, No. II. Annals of the Lyceum of Natural History of New York, 7: 177-246, pls. II, V.

Stimpson, W. 1871. Preliminary report on the Crustacea dredged in the Gulf Stream in the Straits of Florida by L.F. de Pourtales, Assist. U. S. Coast Survey. Part I. Brachyura. Bulletin of the Museum of Comparative Zoology at Harvard College, 2: 109160. 
Verril, A.E. 1908. Decapoda Crustacea of Bermuda. Part I. Brachyura and Anomura, their distribution, variations and habits. Transactions of the Connecticut Academy of Science, 13: 299-474.

Viana, G.F.S.; Ramos-Porto, M.; Santos, M.C.F.; Silva, K.C.A.; Cintra, I.H.A.; Cabral, E.; Torres, M.F.A. and Acioli, F.D. 2003. Caranguejos coletados no norte e nordeste do Brasil durante o Programa REVIZEE (Crustacea, Decapoda, Brachyura).
Boletim Técnico-Científico do CEPENE, 11: 117-144.

Weber, F. 1795. Nomenclator entomologicus secundum entomologiam systematicum ill. Fabricii, adjectis speciebus recens detectis et varietatibus. Chilonii et Hamburg: C.E. Bohn., $171 \mathrm{p}$.

Williams, A.B. 1984. Shrimps, Lobsters, and Crabs of the Atlantic Coast of the Eastern United States, Maine to Florida. Washington, Smithsonian Institution Press, $550 \mathrm{p}$. 